УДК 504.61:621.311.22

(C) 3.С. Сірко, к.т.н.

Національний університет біоресурсів і природокористування України

І.Ю. Вишняков, О.С. Протасов, Н.В. Бірківська

Український державний науково-дослідний інститут «Ресурс»

\title{
РЕКОНСТРУКЦІЯ ІСНУЮЧИХ ПАРОВИХ КОТЕЛЕНЬ В БІОТЕЦ
}

Стаття присвячена висвітленню сутності та змісту такої проблеми як реконструкції існуючих парових котелень, які праиюють на біомасі в БіоТЕЦ.

БІОМАСА, ЕЛЕКТРОЕНЕРГІЯ,
$\begin{aligned} & \text { КОГЕНЕРАЦІЙНА } \\ & \text { ДЕРЕВИННІ ВІДХОДИ }\end{aligned}$

Постановка проблеми. Даною статтею передбачено розглянути проект реконструкції парової котельні в паропоршневу теплоелектростанцію (БіоТЕЦ), що працюе на біомасі (агровідходах, деревинних відходах), з метою генерації та продажу електроенергії за «зеленим» тарифом $[1,2,3]$.

Аналіз останніх досліджень і публікацій. Україна має величезний потенціал у вигляді такого альтернативного джерела енергії, як біомаса. Це продукти, відходи та залишки лісового та сільського господарств (пелети, тріска, тирса, лузга соняшника, солома та ін.), рибного господарства та технологічно пов'язаних 3 ним галузей промисловості, а також складова частина промислових або побутових відходів, здатна до біологічного розкладу.

БіоТЕЦ $є$ запасним, постійно діючим джерелом енергії, що підвищує енергетичну безпеку i незалежність від постачань електроенергії.

Додатково БіоТЕЦ буде місцевим регіональним джерелом електроенергії для населення і підприємств.

Використання біомаси засноване на високоефективному спалюванні, яке дозволяє екологічно безпечно переробити рослинну сировина в електричну енергію, яку продають за пільговим «зеленим» тарифом, і тепло для потреб підприємства (підсушування біомаси, сушки зерна, обігріву виробничих i адміністративних приміщень, забезпечення гарячою водою для санітарно-побутових потреб, опалення теплиці) [4-10]. 
Мета дослідження. Метою дослідження є реконструкція існуючих парових котелень в БіоТЕЦ.

Результати дослідження. В результаті реконструкції парової котельні з'явиться паропоршнева теплоелектростанція «БіоТЕЦ-600» на деревній сировині, електричною потужністю 600 кВт, 3 урахуванням споживання ТЕЦ на власні потреби до 100 кВт/год.

БіоТЕЦ має спеціальний топковий пристрій, який дозволяє використовувати практично будь-яке деревне паливо - від пелет і брикетів до тирси, тріски, глиці і листя, кори та ін., з високою зольністю до $12 \%$ і вологість до $60 \%$.

БіоТЕЦ складається з:

1. Парової котельні 32 паровими котлами, на базі ДКВР 2,5/13, з бункером палива та пристроєм санітарної очистки димових газів. Пропозиція розроблена, як для розміщення на існуючих котельнях, без переобладнання останніх, так і в окремому комплексі, для роботи на твердому паливі будь-якої фракції, зольності і вологістю до $60 \%$.

2. Паропоршневої електростанції, електричною потужністю 600 кВт, на базі 3-х адаптованих під пар дизельних електростанцій АД-200;

3. Системи управління БіоТЕЦ.

Паропоршнева когенераційна установка - це комплекс в складі паропоршневого двигуна з синхронним електрогенератором i блоком утилізації теплоти мастила та теплоти відпрацьованої пари.

Паропоршневий двигун виготовляється шляхом переобладнання поршневого двигуна внутрішнього згоряння.

Паропоршневий двигун працює по 2-х тактному циклі. Питома витрата пара 5 ... 10 кг / кВт * год. Частота обертання валу двигуна - 1500 об / хв., що дуже зручно при стикуванні його з будьяким синхронним електрогенератором. При тиску пари вище 5 бар двигун зберігає потужність по відношенню до вихідного аналогу.

Застосовуючи сучасні електронні пристрої в системі регулювання двигуна виходять якість вироблюваної електроенергії не нижче ніж в мережі.

Вартість 1 кВт встановленої електричної потужності паропоршневої електростанції нижче ніж у виробників парових турбін.

Синхронний електрогенератор - покупний виріб з ККД 92 ... 94\%, що дозволяє перетворювати механічну енергію на валу паро поршневого двигуна в електричну. 
Електрогенератори застосовуються для дизельних, бензинових і газових електростанцій можуть бути використані без доопрацювань на паропоршневих електростанціях.

Блок утилізації теплоти - при роботі паропоршневого двигуна частина теплоти пару передається мастильному маслу. Сучасні мастила можуть працювати при температурі до $130{ }^{\circ} \mathrm{C}$. При більш високих температурах масло втрачає мастильні властивості, його необхідно охолоджувати, тобто відбирати частину теплоти і направляти іiі для виконання корисної роботи. До того ж масло виконує функції охолодження двигуна.

Пар, який виконав корисну роботу в двигуні, повинен бути конденсований і відправлений в паровий котел. При конденсації пари виділяється теплота, яка також може бути утилізована i відправлена для виконання корисної роботи.

Паропоршнева електростанція 200 кВт виробляється компанією «Сврогаз» при інституті газу Національної академії наук, шляхом адаптації під пар дизельної електростанції ЕСД 200-Т / 400 стаціонарного виконання на базі швидкохідного чотиритактного 12-циліндрового двигуна 1Д12, 3 водяним охолодженням.

Станції можуть бути обладнані щитом автоматичного керування з контролером АВР, капотом.

Дизельний мотор переробляється в паропоршневий двигун.

Дизель-генератори можуть працювати як автономно, так і в паралель між собою, з іншими однотипними дизель-генераторами або із загальною промислової мережею.

Деревинні - та агровідходи привозять на територію БіоТЕЦ і складають на відкритому майданчику з твердим покриттям. У дощовий і сніговий сезони відходи накривають тентами.

Тюкована рослинна сировина, наприклад солома, подається в подрібнювач, а потім подається в бункер накопичувач палива i далі в топку.

Лушпиння подається відразу конвеєром подачі палива засипається в топку. Парогенератор нагріває підготовлену воду, і передає під тиском до $13 \mathrm{MПа} \mathrm{паропоршневій} \mathrm{машині.} \mathrm{Топка}$ парогенератора обладнується гратами 3 шуруючою рамкою, що охолоджуються водою (ТУ У 28.2-32831406 - 003: 201). Робота топки механізована із застосуванням електроприводів i автоматизована в обсязі необхідному для нормальної експлуатації установки, що працює на спалюванні твердого палива.

Для ефективного горіння палива під грати в зону первинного дуття подається гаряче повітря температурою 200- 
$400^{\circ} \mathrm{C}$. Для повного спалювання палива i зменшення виносу в камеру топки подається повітря в зону вторинного дуття. Переміщення і розрівнювання шару палива по гратах відбувається за допомогою шуруючої рамки відбувається шурування шару, що інтенсифікує процес згоряння палива.

В установці прийнята схема сухого золовидалення. 3 топки парогенератора зола скидається на гвинтовий конвеєр, який транспортує продукти спалювання в зольник.

Вихідні димові гази з конвективної частини парогенератора потрапляють в пристрій санітарної очистки газу (ПСОГ ТУ У 29.732831406 - 004: 201), де очищуються до вимог екологічних норм i далі димососом викидаються в атмосферу через димову трубу.

ПСОГ забезпечує ефективність очищення димових газів до $98 \%$.

Рослинне паливо в теплогенераторі перетворюється в золу - натуральне мінеральне калійне добриво.

Зола видаляється шнеком в бункер золи, звідки вивозяться на майданчик зберігання, для відвантаження покупцям.

В якості палива в можна використовувати:

1. Пелети і брикети всіх видів та 3 різної рослинної сировини (деревина, солома, лушпиння соняшника, кукурудза, сіно, трава, листя і глиця, кора);

2. Дерев'яну тріску і тирсу любих порід дерев і чагарників вологістю до $50 \%$; інше);

3. Кускові деревинні відходи (обрізки, пеньки, кора та

4. Солома, сіно, трава, листя і глиця, кора;

5. Лушпиння соняшника та зерна;

6. Торф (у вигляді пелет і брикетів) - при необхідності.

У разі використання тюкованих агровідходів необхідно додатково придбати і встановити січкарню.

Подрібнена сировина механічно подається 3 подрібнювача в сушарку, де воно підсушується до 12\% вологості.

У сушарку подається енергоносій - димові гази з парового котла.

Подрібнена і підсушена сировина витягується димососом в циклон, де відділяється підготовлена сировина від димових газів.

У димову трубу виводяться СО2 і СO.

Продукцією БіоТЕЦ буде:

1) «зелена» електроенергія;

2) тепло;

3) відходи - зола. 
Отримані:

1) електрика буде продаватися державі в енергоринок;

2) тепло буде використовуватися на місці для:

- опалення адміністративних і виробничих приміщень;

- сушки зерна;

- отримання гарячої води для санітарно-побутових цілей;

- опалення теплиці;

3) зола може використовуватися в якості натурального мінерального калійного добрива.

Для реалізації проекту буде створено підприємство «Ботанік ТЕЦ 2», яке отримає необхідні ліцензії на генерацію і продаж електроенергії.

Умови передачі території для розміщення БіоТЕЦ підлягають окремому узгодженню і уточненню.

Проекти будівництва об'єктів електроенергетики, що використовують альтернативні (відновлювані) джерела енергії, мають право на реєстрацію в якості проектів спільного впровадження в рамках дії Кіотського протоколу.

Механізм спільного впровадження діє на умовах спільного впровадження, при яких інвестор фінансує заходи 3 виконання проекту, отримуючи натомість офіційно оформлені величини скорочення викидів (ОСВ). Законодавством України передбачено низку пільг щодо оподаткування діяльності пов'язаної з розробкою і впровадженням енергозберігаючих заходів та енерго ефективних проектів.

Залежність України від імпорту основних енергоносіїв змушує уряд і бізнес розвивати альтернативну енергетику, яка зараз займає $0,2 \%$ в загальному енергобалансі країни (в Євросоюзі іiі частка досягла $10 \%$ ).

Економічна доцільність створення Проекту виникла завдяки прийняттю Закону України «Про електроенергетику» від $16.10 .1997 \mathrm{p}$, за яким закупляється електрика, вироблена 3 використанням альтернативних джерел електроенергії. Чинний «зелений» тариф робить будівництво біоелектростанцій, що працюють на біомасі, економічно привабливим проектом.

Висновки. Заміщення викопних видів палива деревинними відходами та агробіомасою $є$ дуже перспективним варіантом декарбонізації сектору теплопостачання. Пошук і використання альтернативних видів палива, альтернативність яких полягає, передусім, в їхній екологічності та відновлюваності, надають додаткові джерела енергетичних ресурсів. 
Проект «БіоТЕЦ» розроблений як інструментарій для створення сприятливих умов 3 метою широкого розповсюдження систем опалення 3 використанням деревинних відходів та агробіомаси.

\section{Література}

1. M.W.Vis, D.van den Berg. Biomass Energy Europe Harmonization of biomass resource assessments. Volume I. Best Practices and Methods Handbook. - November 2010. - 220 p.

2. Закон України №514-VIII від 04.06.2015 «Про внесення змін до деяких законів України щодо забезпечення конкуретних умов виробництва електроенергії з альтернативних джерел енергії»

3. Підготовка та впровадження проектів заміщення природного газу біомасою при виробництві теплової енергії в Україні. Практичний посібник/ За ред. Г. Гелетуха. - К.: «Поліграф плюс», 2015. - 72c.

4. Посібник. Технології та обладнання для використання поновлювальних джерел енергії в сільськогосподарському виробництві/ За ред. Кравчука В.І., Дубровіна В.О. - Дослідницьке: УкрНДІПВТ ім. Л. Погорілого. - 2010. - 184 с.

5. Справочник потребителя биотоплива/ [ под ред. Виллу Bapeca]. Таллин: Таллинский технический университет, 2005. $183 \mathrm{c}$.

6. Виробництво теплової енергії із біомаси. Аналіз законодавства, регулярних аспектів i податкової політики та рекомендації щодо неодмінних змін у чинному законодавстві. Звіт, підготовлений ВБО «Інститут місцевого розвитку» у рамках виконання Проекту «Місцеві альтернативні джерела енергіі: м. Миргород». - К., 2014. - 100с.

7. Добрива та їх використання: Довідник. - К.: Арістей, 2010. $254 \mathrm{c}$.

8. Біологічні ресурси і технології виробництва біопалива: Монографія/ Я. Б. Блюм, Г. Г. Гелетуха, І.П. Григорюк, К.В. Дмитрук, В.О. Дубровін, А.І. Смець, Г.М. Забарний, Г.М. Калетнік, М.Д. Мельничук, В.Г. Мироненко, Д.Б. Рахметов, А.А. Сибірний, С.П. Циганков. - К.: Аграр Медіа Груп, 2010. - 408c.

9. Энергетическое использование древесной биомассы: заготовка, транспортировка, переработка и сжигание: учебное пособие для студентов высш. учебных заведений/ авт.-сост. В.С. Сюнев [и др.]. - Петрозаводск: Издательство ПетрГУ, 2014. - 123с.

10. Твайдел Дж., Уэйр А. Возобновляемые источники энергии. Пер. с англ. - М: Энергоатомиздат, 1990. - 392с. 